\title{
TERRITORIAL MARKETING AS AN ELEMENT BOOSTING THE DEVELOPMENT OF A COMMUNE
}

\author{
Małgorzata Renigier-Biłozor, PhD \\ Faculty of Geodesy, Geospatial and Civil Engineering \\ University of Warmia and Mazury in Olsztyn \\ e-mail: malgorzata.renigier@uwm.edu.pl
}

\author{
Andrzej Biłozor, PhD \\ Faculty of Geodesy, Geospatial and Civil Engineering \\ University of Warmia and Mazury in Olsztyn \\ e-mail:malgorzata.renigier@uwm.edu.pl
}

\begin{abstract}
Recently, it has become popular to streamline the way of managing territorial units by adapting the marketing approach to a territorial dimension. The majority of cities and communes in Poland have realized that, in order to achieve their set goals under conditions of fierce competition for limited resources, it is necessary to introduce territorial marketing as one of the key and significant own tasks to be implemented. The objective of the article is to develop principles of the effective use and management of the area of a commune by carrying out suitable marketing projects, based on an analysis of the social, economic and geopolitical situation of the commune, with particular emphasis placed on location factors.
\end{abstract}

Key words: territorial marketing, commune land management, development of territorial unit.

JEL Classification: R13, R30, R58.

Citation: Renigier-Biłozor M., Biłozor A., 2015, Territorial Marketing as an Element Boosting the Development of a Commune, Real Estate Management and Valuation, Vol. 23, No. 2, pp. 38-49.

10.1515/remav-2015-0014

\section{Introduction}

Knowledge on the territorial marketing of regions and cities has become increasingly popular and considerably influences the economic success of and living standards in particular local government units. Territorial marketing, as a process supporting the management of a territorial unit, becomes a prerequisite for running an effective spatial planning policy in the area of a commune. Territorial marketing activities are undertaken by different types of entities, including local government units and non-governmental, public, private, group and individual entities. Consistent activities and the mutual cooperation of all marketing initiators and animators in a given area facilitate more effective and efficient achievement of set goals.

According to SZROMNIK (2010), marketing might be defined as a "specific way of thinking about success in contemporary business". In line with this definition, territorial marketing is a "philosophy of achieving set goals by settlement units in conditions of competition for limited resources, underpinned by the conviction that proper orientation towards customers-partners has a critical impact on the achieved results."

The most important objective of municipal marketing is to create a competitive advantage (KORNAK, RAPACZ 2001) by developing and applying a proper "set of instruments and measures that aim to increase the competitive capacity of a separate and developed territory (town/city, commune, tourist region) in relation to other territorial units of this type". 
By generalizing the above definitions, it is possible to conclude that territorial marketing constitutes the entirety of measures taken by animators with the aim of improving the image of a given region and integrating local and external communities with this region (commune, city). This is achievable by providing a given community with the proper direction of development of appropriate spheres of life, which results from the analysis of the geopolitical, social, economic and "image" conditions of a given area (RENIGIER-BIŁOZOR, PIECHNA 2010).

The assumptions of territorial marketing have been used by foreign territorial units for a long time. Recently, they have been used with great success by Polish entities and are presented in the examples cited, i.e. in the following publications: DINIS (2004), DINNIE et al. (2010), RENIGIER-BIŁOZOR, PIECHNA 2010, ŹRÓBEK et al. 2012 ŹRÓBEK and GROSS (2013), WALACIK (2013), SUCHACEK (2008). The analysis of the experiences of numerous foreign and Polish cities shows that the implementation of the principles of territorial marketing spurs and even determines the achievement of set goals and favourably affects the more dynamic development of regions (i.e. ANHOLT 2007, BIŁOZOR 2010, DE CHERNATONY 1999, CHANG 2000, KOTLER 2011).

The main objective of the article is to analyze and determine the directions of marketing projects in the context of boosting the development of a commune on the example of the Pisz commune. The work proposed a procedure for building a marketing strategy in the form of sequential stages that include: an analysis of the values, development potential and weaknesses of the subject unit, and an inventory and assessment of the current marketing activities taken by the commune, the expectations and needs of recipients, as well as the opportunities and potential to use territorial marketing tools for the purpose of achieving optimal development goals of the commune. The conducted research aims to prove the thesis that territorial marketing constitutes an essential element in boosting development of a commune through activating the local community, as well as building bonds and a sense of identity among its inhabitants.

\section{Territorial marketing implemented within a territorial unit}

The marketing activities of a region should be aimed at gaining new resources and improving the quality and effectiveness of a project implemented by a territorial unit, which is targeted at meeting the specific needs of a community (FLOREK 2006). In a strategic dimension, the aims of territorial marketing might be specified as three targeted objectives (SZROMNIK 2010):

- building a positive image of a commune, region and local units,

- improving the quality of services delivered by public entities (in the context of difficult-to-reach services for business entities and inhabitants),

- improving the attractiveness and competitiveness of rival cities, rural communes, regions or districts.

During the process of formulating strategic goals, importance is placed on their continuity, while their further implementation should be independent of changes among territorial unit authorities. Any possible modifications in the assumptions of a strategy are allowed in terms of the tools used and the manner by which the planned goals are implemented (DOMAŃSKI 2006). For the purpose of simplifying territorial marketing analyses, the concept of a "megaproduct" has been introduced as a basic research unit. From the marketing perspective, a product is a broad term and comprises a lot of elements that are difficult to measure, e.g.: location, climate, natural environment, etc. It also includes elements such as: human capital, transport and organizational conditions (MARKOWSKI 1999). A megaproduct is defined as an offer of a territorial unit and includes interrelated material and nonmaterial products that are available to particular users for a fee, partly for a fee, or free of charge (MARKOWSKI 2006). A key advantage of permanent or temporary stay in a given area should be the reaping of benefits from local social, intellectual, infrastructural, cultural and natural values (FLOREK 2006).

The practical influence of a "territorial megaproduct" on internal and external target markets requires using a set of marketing tools referred to as the marketing mix. The most popular mix of marketing tools transferred to the territorial marketing dimension is a set of elements such as: product, price, distribution and promotion. Within this concept, the use of marketing tools includes (SZROMNIK 2006):

- product - a proper mix of the marketing features of a product, 
- price - proper conditions for pricing in the case of transactions made with the participation of local government units,

- distribution - proper offer of a product, i.e. right selection of location, time and form,

- promotion - a suitable form and manner of promotion.

A different approach to the tools of marketing impact on the recipients of a territorial "megaproduct" was proposed by Kotler et al. (2003). This marketing mix is composed of the following tools:

- infrastructure - developing the specification of an area,

- people - quality of service offered by the personnel of a local government unit office and the relations of inhabitants with people from the outside,

- attractions - organizing regular and one-time events, and mass events,

- image and quality of life - creating a positive image of an area, effective informative activities and propaganda.

The mix of territorial marketing tools should be adapted to the individual conditions of the given territorial unit and adjusted so as to maximize the results of marketing activities and bring them closer to meeting the set objectives.

\subsection{Marketing strategy of a territorial unit}

One of the main objectives of territorial marketing is seeking new trends and reasons for attracting people. According to SZROMNIK (2010), the proper realization of marketing targets by territorial units requires first systematizing and planning the whole impact process on addressees. This can be achieved by means of a marketing strategy, which is a special mix of predicted marketing measures taken by a territorial unit to influence particular groups of recipients.

Developing the marketing strategy of an administrative unit entails the need to conduct a range of a priori analyses related to diagnosing the condition and needs of a given territorial unit in light of the social, economic and geopolitical situation, human and natural capital, as well as strengths and weaknesses. According to SZROMNIK (2010), an operational and functional marketing strategy of a territorial unit includes four main stages: an analysis of the situation, defining the philosophy of goals, strategic and operational planning, and the implementation and control of actions.

\subsection{Developing a marketing strategy on the example of the Pisz commune}

Developing a marketing strategy for the chosen territorial unit was divided into respective task stages. Subsequent stages were developed according to an individual concept, taking into account theoretical assumptions of territorial marketing, as well as their practical implementation, which results from the marketing strategy and utilitarian character of the presented assumptions.

The results of the research are presented on the example of the Pisz commune, which was selected due to, e.g., the lack of a marketing strategy and the serious social and economic problems of this region of Poland, including: high unemployment rate, the migration of its population and no shorttime perspectives of change, etc.

In the first stage, the subject of the research was analyzed, diagnosing problems, on one hand, and the main values and social and economic potential of the Pisz commune on the other (on the basis of a study of the conditions and directions of development and the strategy of development of the Pisz commune). The most important conclusions from the first stage have been presented below.

The Pisz commune is a rural and urban commune located in the North-East of Poland, in the district of Pisz of the Warmia-Masuria Province. As data from the General Statistical Office shows, 27,974 people, including $70.2 \%$ of urban inhabitants and $29.3 \%$ of rural inhabitants, lived in the area of the Pisz commune in 2012. In terms of area, it is the largest commune in Poland. It covers an area of $63.370 \mathrm{ha}$, including $98.4 \%$ of rural areas. Over the recent years, young inhabitants have left the commune; yet despite this fact, a steady growth of population has been observed. The Pisz commune is located in a district with a constantly growing unemployment rate (in 2012, it was over 30\%). Over the recent years, the number of registered business entities per 10,000 inhabitants was approximately 810 (Central Statistical Office). The prevailing percentage of people is employed in agriculture and forestry, and in companies that process agricultural products (STRATEGY OF THE DEVELOPMENT OF THE COMMUNE). In the area of the administrative unit, there are two manufacturing plants that employ approximately 900 employees in total. Both companies operate in the wood industry. The budget of the Pisz commune has been in a deficit since 2008, and this deficit has been growing each year. 
The area of woodlands in the commune was 28.798 .7 ha in 2012, and the level of forestation was $45.45 \%$ (General Statistical Office). Legally protected areas in the territorial unit cover $55.7 \%$ of the land. The Pisz commune has 54 immovable monuments and one urban layout entered into the register of monuments (COMMUNE PROTECTION PROGRAM...). The potential of animate and inanimate nature elements may be of special value for the analyzed commune. Unique landmarks that have historic and aesthetic value are potential and significant attributes for building an image of the commune.

To sum up, there are alarming demographic trends and difficulties in maintaining stable economic growth in the Pisz commune. The key employment sectors in the analyzed unit are agriculture and forestry, while industry is related to wood processing. Simultaneously, the geographical location and natural conditions considerably influence the tourist attractiveness of the area.

The second stage of the developed strategy is based on identifying the tools of marketing impact currently used by the local government unit of the Pisz commune. The analysis shows that the commune does not have a strategy of marketing activities, so the authors based their research regarding the inventory of marketing projects mainly on the Strategy of Development of the Pisz Commune for 2007-2015 and the information presented on the official Internet portal of the commune: www.pisz.pl. A shortened description of measures taken by the commune has been presented below.

Building its strategy of development, the Pisz commune defined objectives that will support local, social and economic progress in the long-term perspective. These goals relate to tourism, the development of entrepreneurship and the services market, and an improvement in the quality of life of its inhabitants. The Town and Commune Office of Pisz have a specialized organizational unit - the Department of Civil Affairs, Promotion and Tourism. The local government authority of the commune is focused on the development of tourism, thus placing emphasis on tourist and nature values by running promotional campaigns. As regards pro-investment activities, the unit has initiated measures aimed at gaining investment capital for less than two years. The projects carried out in this respect are based only on the organization of conferences. Over the recent years, the commune has participated in a local government project that helps to diagnose investment potential and draw up an investment offer.

The third stage of the developed strategy was based on making an attempt to evaluate the marketing activities of the territorial unit. According to the authors, on the basis of the aforementioned analyses, the measures taken are insufficient; they lack creativity and do not bring the desired effects. Questionnaire surveys were carried out to increase the objectivity of these measures. The questionnaires (Attachment No. 1) were addressed to a group of 150 randomly selected respondents (petitioners of the town office) who have a permanent place of residence in the researched commune and are within the age group of 25 to 60 years old.

The evaluation of the marketing activities of the local government unit was divided into three categories:

- I - characterizes units with a poor use of territorial marketing tools,

- II - characterizes units with a moderately satisfying level of marketing activities; the implemented projects and use of tools of marketing impact are insufficient,

- III - characterizes units with a satisfying level of development and implementation of marketing activities.

As the analysis of the research results shows (Attachment No. 1), the mean number of points that falls per one questionnaire amounts to 21 (out of a maximum of 40 points).

This result is near the median, so it is possible to assume that the opinion of inhabitants neither particularly differentiates the commune nor negates it in this respect. Consequently, the Pisz commune was qualified into category II, and its measures as regards territorial marketing described as being at a moderately satisfying level. Detailed analysis revealed that the respondents gave a positive assessment of the commune officials and promotional activities. Negative opinions concerned mainly the sphere of communication between the authorities and the local community, the atmosphere in the commune and the sphere of managing the unit.

On the basis of the aforementioned survey and own analysis of the subject matter, it can be concluded that, although the territorial unit is located in an attractive region in terms of the development of tourism, it does not demonstrate features typical of an attractive tourist location. The local government authorities and local entrepreneurs initiate the creation and promotion of different tourist products, however, the neighbouring communes attract a significantly greater number of 
holiday-makers and enthusiasts of active tourism. The town has gained a somewhat attractive image, yet it lacks a unique atmosphere and interesting architectural forms. Inhabitants of the commune struggle with a serious unemployment problem, and the labor market is unstable and revived only in summer. This problem causes dissatisfaction and worries the local community; moreover, it results in the migration of young and educated people.

Subsequently, the fourth stage of the analyzed strategy regards the selection of the directions of territorial marketing activities. The selection of an optimal direction of territorial marketing activities was based on the analysis of the main social and economic needs of the subject unit (LESZCZYŃSKA 2013, STRATEGY OF DEVELOPMENT...) and on the opinion of the local community, as well as a report published by the Center for Regional and Local Analyses that relates to the investment attractiveness of the Warmia-Masuria Province (INVESTMENT ATTRACTIVENESS OF REGIONS 2010).

The opinion of the community was defined on the basis of questionnaire surveys (Attachment No. 2) carried out on a sample of 160 randomly selected inhabitants aged between 20 and 45 (professionally active people). The respondents specified areas where they see potential for using marketing activities and preferred tools of marketing impact which, in their opinion, should be used by the Pisz commune. The results of the questionnaire have been compiled and presented in Tables 1 and 2 for respective key issues. According to the local community (Tab. 1), the local labor market should develop mainly in the industrial, services and trade sectors.

Table 1

The directions of development of the labor market in the Pisz commune according to the opinions of inhabitants (Attachment No. 2)

\begin{tabular}{ccc}
\hline \multirow{2}{*}{ No. } & Specification & Number of responses \\
\hline 1 & industry & 132 \\
\hline 2 & tourism services & 123 \\
\hline 3 & trade & 114 \\
\hline 4 & other services & 75 \\
\hline 5 & small services & 57 \\
\hline 6 & heavy industry & 27 \\
\hline 7 & forestry & 21 \\
\hline 8 & agriculture & 9 \\
\hline 9 & education & 6 \\
\hline 10 & other & 3 \\
\hline 11 & Total & 480 \\
\hline
\end{tabular}

Source: authors' work on the basis of a conducted questionnaire survey.

On the basis of the results of the conducted research (question No. 2 of the questionnaire from Attachment No. 2), it is possible to conclude that inhabitants of the Pisz commune hold a clear position as regards the direction of using tools of marketing impact. The community of the commune sees the effective use of territorial marketing in tourism (48 answers out of 160 possible ones) as well as the development of the labor market in industry (32 answers) and commerce (31 answers).

Taking appropriate measures in the scope of territorial marketing might bring a number of benefits for the territorial unit and increase its competitiveness. The results of projects preferred by the general public taht can possibly raise the attractiveness of the Pisz commune have been listed in Table 2 (Attachment No. 2, question No. 3).

According to the respondents, the crucial measures that should be taken by the Pisz commune to increase its competitive position include road investments, cooperation with local entrepreneurs and preparing an investment offer. Measures targeted at increasing the standard of services offered by civil servants and the modernization and extension of sports and leisure facilities were also indicated as necessary, though to a lesser degree. The respondents expressed an opinion that the aestheticization of an area, taking care of the natural environment and enhancing the educational offer at local schools might contribute to an increase in the attractiveness of the Pisz commune to a minimal degree. 
Table 2

The opinion of the local community on increasing the competitiveness and general attractiveness of the territorial unit (Attachment No. 2)

\begin{tabular}{clc}
\hline No. & \multicolumn{1}{c}{$\begin{array}{c}\text { Activities which might influence an increase in the } \\
\text { competitiveness of the Pisz commune and its general } \\
\text { attractiveness }\end{array}$} & $\begin{array}{c}\text { Percentage } \\
\text { of responses }\end{array}$ \\
\hline 1 & $\begin{array}{l}\text { Greater communication accessibility, building new communication } \\
\text { routes and modernization of the existing ones }\end{array}$ & $92 \%$ \\
\hline 2 & $\begin{array}{l}\text { Cooperation with local entrepreneurs with the aim of stimulating } \\
\text { the local labor market }\end{array}$ & $90 \%$ \\
\hline 3 & Preparing a comprehensive offer for potential investors & $78 \%$ \\
\hline 4 & $\begin{array}{l}\text { Promotion of the commune's values targeted at different groups of } \\
\text { recipients }\end{array}$ & $75 \%$ \\
\hline 5 & $\begin{array}{l}\text { Improving qualifications of civil servants and preparing systems of } \\
\text { petitioners' service, introducing improvements in procedures }\end{array}$ \\
\hline 6 & $\begin{array}{l}\text { Modernization and extension of leisure and sports facilities with the } \\
\text { aim of increasing tourist attractiveness }\end{array}$ & $74 \%$ \\
\hline 7 & $\begin{array}{l}\text { Modernization and development of sanitary and sewage } \\
\text { infrastructure }\end{array}$ & $\begin{array}{l}\text { Pursuing a reliable and regular information policy among } \\
\text { inhabitants and other stakeholders }\end{array}$ \\
\hline 9 & $\begin{array}{l}\text { Running revitalization activities in rural and urban areas, } \\
\text { aestheticization and use of public lands }\end{array}$ & $37 \%$ \\
\hline 10 & $\begin{array}{l}\text { Improving the natural environment through implementation of } \\
\text { forest and lake treatment programs, pro-environmental education }\end{array}$ \\
\hline 11 & $\begin{array}{l}\text { Expanding the educational offer at local education establishments } \\
\text { and setting up a branch of a higher school in the Pisz commune }\end{array}$ \\
\hline
\end{tabular}

Source: authors' work on the basis of a conducted questionnaire survey.

A further question (No. 4, Attachment No. 2) regarded using suitable tools by the authorities of the commune to accelerate the process of obtaining new investors. Inhabitants of the unit $(85 \%$ of respondents) stated that the comprehensive development of lands for investment with the commune's own resources can best contribute to the attractiveness of an investment offer. The second most common incentive indicated was the granting of concessions and exemptions from local charges and taxes. In third place, with $71.7 \%$ votes, was the possibility of paying tax liabilities in instalments or with an extended deadline. Only 5\% of respondents indicated that the commune should utilize its own financial means to carry out an investment project.

The direction of marketing activities for the unit was also defined on the basis of analysis of the report on the investment attractiveness of the commune, which was published by the "Center for Regional and Local Analyses" for the Warmia-Masuria Province and titled: "INVESTMENT ATTRACTIVENESS OF REGIONS" (2010). As the information presented in Figure 1 shows, location values for investments in the Pisz commune in 2010 were described as attractive in the context of the whole domestic economy (C class). Higher than average marks for potential investment attractiveness were received by the analyzed unit in the areas of industry, commerce, and professional, scientific and technical activities.

As the research and analyses show, gaining a large investor for one of the industries for which the Pisz commune has a higher than average attractiveness might become a booster of social and economic growth of the region. Taking into account the small quantity of natural resources and restrictions related to areas under legal protection, the Pisz commune has little chance for the development of heavy industry. The area of the commune abounds in wood material resources, and there are two plants operating in the wood industry. Using the present potential of the existing 
resources and operation of companies in this industry in the area of the Pisz commune is the key to directing marketing activities of the territorial unit in order to gain an investor operating in the wood and paper industry.

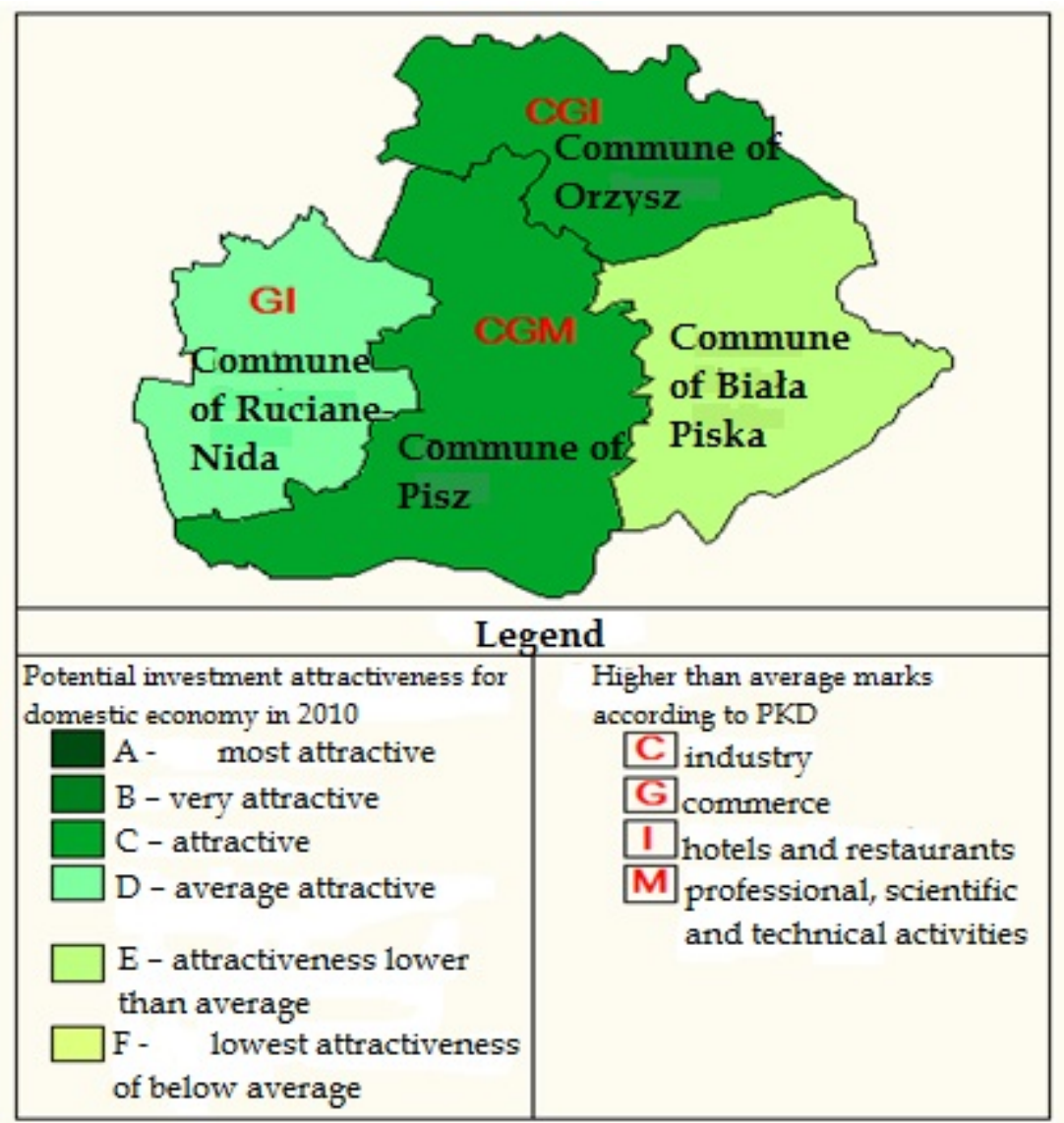

Fig. 1. Potential investment attractiveness of the communes of the Pisz district in 2010. Source: authors' work on the basis of "Investment Attractiveness of Regions" (2010).

However, a new incentive for growth would be establishing cooperation with a foreign investor, which would lead to carrying out a large investment project, the inflow of investment capital and social and economic growth. Therefore, the investment offer of the Pisz commune should be addressed not only to domestic entities, but should be taken beyond the borders of the country. To make an offer match foreign investors' expectations in the best way possible, expectations and motives for locating investment projects by foreign investors were researched.

Given the need to recognize these expectations, the authors made us of the results of a research project titled "The Role of Direct Foreign Investments...." (DOŻYŃSKI et al. 2011). Research was carried out in 2010 on a group of 188 foreign investors, and the subject of the research was, inter alia, the reasons for locating investments in Poland and expectations of foreign investors with regard to public administration. In the aforementioned research, respondents specified the significance of eleven factors that, in their opinion, influenced locating an investment in Poland. As the conducted research shows, the most important factor that influenced locating an investment in Poland was the aspect of a cheap, qualified work force and, secondly, the financial aspect in the form of low costs and surcharges. For investors, the absorptive power of the Polish market for products or services they produce was also important, as well as the presence of Polish trading partners and suppliers from a given industry. In the analyzed research project, an attempt was made to provide a diagnosis of foreign investors' expectations in relation to public administration. As the aforementioned analysis shows, financial preferences were the most popular expectations of investors in relation to public administration. In the context of territorial units, they concerned reductions of local charges and taxes, and establishing special privileges for investors. Every third respondent highlighted the need to simplify regulations and procedures, and reduce bureaucracy. The respondents usually indicated the preferred qualities of 
civil servants, e.g. knowledge of foreign languages, friendly attitude towards investors, availability, high professional qualifications (DOŻYŃSKI et al. 2011).

Summing up the above stage, it can be stated that the Pisz commune should find its main direction of development and use its potential in an economic sector other than tourism. Due to its natural environment values, the commune should further implement measures that aim to develop its tourist function, yet this should be rather an addition to the main industry. This results from the fact that tourism in this region is usually seasonal, and requires huge expenditure to attract large numbers of tourists and become competitive in relation to the neighboring communes.

The fifth stage of the discussed concept was based on describing the basic marketing activities of the commune in the scope of implementing a territorial marketing strategy. Defining the concept underpinning territorial marketing of the commune was done on the basis of combining the preferences and expectations of the local community and external investors, accounting for the individual capabilities of the Pisz commune and implemented projects in the scope of territorial marketing.

It has been agreed that one of the main recipients of marketing activities, in addition to those specified in the concept (i.e. the local community and tourists), will be foreign investors aiming to carry out industrial investments based on wood processing, including all branches of the wood and paper industry. The structure of this concept was based on six areas of proposed activities (Fig. 2). The concept includes detailed proposals for activities agreed upon in compliance with investors' expectations, the specificity of the commune and the possibilities of their implementation.

Technical infrastructure and investments in
land use:
- drawing up local land use plans
- drawing up a plan of adapting the main
communication routes of the commune, its
access roads around lands offered for the
passage and service of heavy goods delivery
vehicles;
- continuation of a pro-investment policy in
technical infrastructure and programs of
land use and the aestheticization of an area;
- renovation of the railway and bus station.

Investment offer and pricing
instruments:
- identification and preparation of lands
for investment;
- land development;
- a proposal of tax concessions and
exemptions;
- preparing documentation required to
conclude a contract.
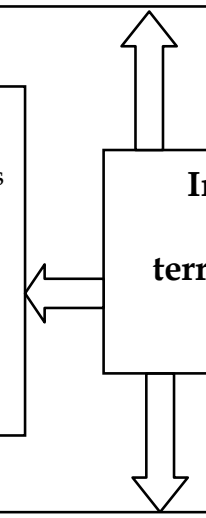

Cooperation with local entrepreneurs and creating a pro-investment climate among the local community:

- establishing collaboration and cooperation between the commune and local companies;

- providing mutual support and assistance which will boost the commune's credibility as a commune friendly in relation to current and prospective entrepreneurs who operate in this area;

- informing the local community on foreign investments and presenting possible benefits of their implementation in the area of the commune. 
Fig. 2. Basic activities in the scope of implementing a marketing strategy. Source: authors' own work.

\section{Summary}

Territorial marketing has been increasingly used by local government units to achieve set goals more effectively. Territorial marketing, as a field of knowledge, refers not only to the promotion of a region, but the whole range of tools influencing a market, such as: defining the features of a territorial product, its proper distribution, proper communication with recipients or creating a positive image of an area and building an identity with this area.

The effective use of knowledge and tools provided by territorial marketing is possible provided that a proper action plan is developed and marketing animators are coordinated effectively. Specifying the needs and objectives of a given territorial unit should be based on a detailed analysis of its strengths, weaknesses, potential, and the expectations of recipients.

On this basis, the outline for building a territorial marketing strategy was prepared according to the following stages, i.e.: the analysis of strengths, weaknesses and the social and economic potential of a particular territorial unit, the specification of the market impact tools used by the unit, assessment of the effectiveness of marketing activities taken by the territorial unit under consideration, selection of an optimal direction of territorial marketing activities, and the implementation of tasks set out by a developed territorial marketing strategy.

A properly developed and implemented marketing strategy is an effective tool that helps to bring numerous benefits to a territorial unit, in particular, the increase of its competitiveness. Using assumptions of territorial marketing to activate a local community and build bonds and a sense of identity allows for the stronger stimulation of the development of a commune.

\section{References}

ANHOLT S., 2007, Competetive identity: The new brand management for nations, cities and regions, Palgrave Macmillan, London, UK.

ATRAKCYJNOŚĆ INWESTYCYJNA REGIONÓW, (Investment attractiveness of the regions), (2010), http:/ / www.paiz.gov.pl/files/?id_plik= 11044

BiŁOZOR A., 2010, Zarządzanie przestrzenią miejską, (Management of urban space), Zeszyty Naukowe Wyższej Szkoły Bankowej w Poznaniu Nr 27/2010. Wydawnictwo Wyższej Szkoły Bankowej w Poznaniu.

CHANG T. C., 2000, Renaissance revisited: Singapore as Global City for the arts. International journal of urban and regional research, Vol. 24, No. 4, pp. 818-831.

DE CHERNATORY L., 1999, Brand management through narrowing the gap between brand identity and brand reputation, Journal of Marketing management, Vol. 15, Nos. 1-3, pp. 157-179.

DINIS A., 2006, Marketing and innovation: Useful tools for competitiveness in rural and peripheral areas, European planning studies. Vol. 14 Issue 1 pp: 9-22

DINNIE K., MELEWAR, T. C., SEIDENFUSS, KAI-UWE; et al. 2010, Nation branding and integrated marketing communications: an ASEAN perspective, International marketing review Vol. 27 Issue 4 pp. 388-403

DOMAŃSKI T., 2006, Skuteczna promocja miasta i regionu podstawowym zadaniem marketingu terytorialnego, (Effective promotion of the city and the region of territorial marketing basic task), W: MARKOWSKI T. (red). Marketing terytorialny. tom CXVI, Komitet Przestrzennego Zagospodarowania Kraju PAN, Warszawa, pp. 124-139.

DOŻYŃSKI T., URBANIAK W., DOROŻYŃSKA A., 2011, Raport częściowy. Ocena działalności inwestorów zagranicznych w województwie łódzkim, (Partial report. Assessment of foreign investors Łódź Voivodeship). Łódź.

FLOREK M., 2006, Podstawy marketingu terytorialnego, (Fundamentals of territorial marketing). Wydawnictwo Akademii Ekonomicznej w Poznaniu, Poznań.

GMinNy PROGRAM OPIEKI NAD ZABYTKAMI GMINY PISZ (Community programme of Monuments protection of PISZ) 2011-2014.

Gross M., Źróbek R., 2013, Public real estate management in postsocialist countries. Real Estate Management and Valuation. Vol. 21, Issue 4, pp. 11-16,

GUS http://www.stat.gov.pl, 15.04.2013. 
HuCZEK M., 2007, Promocja gminy jako sposób wspierania lokalnego rozwoju społecznogospodarczego, (Promote the municipality as a way to support local socio-economic development). Oficyna Wydawnicza „Humanitas”, Sosnowiec.

KORNAK A.S., RAPACZ A., 2001, Zarządzanie turystyką i jej podmiotami w miejscowości i regionie, (Tourism Management and its items in the city and the region). Wydawnictwo Akademii Ekonomicznej we Wrocławiu, Wrocław.

Kotler P., Haider D., Rein I., 1993, Marketing Places. Pub. Free Press. New York

Kotler P., 2011, Reinventing Marketing to Manage the Environmental Imperative. JOURNAL OF MARKETING . Vol. 75, Issue 4 pp. 132-135

LESZCZYŃSKA M., 2013, Ocena i analiza działań marketingowych gminy Pisz, (Assessment and analysis of marketing activities Pisz municipality). Praca inżynierska. UWM Olsztyn

MARKOWSKI T., 1999, Zarządzanie rozwojem miast, (Management of of urban development). Wydawnictwo Naukowe PWN, Warszawa.

MARKOWSKI T., 2006, Marketing miasta (City marketing). W: MARKOWSKI T. (red). Marketing terytorialny. tom CXVI, Komitet Przestrzennego Zagospodarowania Kraju PAN, Warszawa, pp. 89-120.

RENIGIER-BIŁOZOR M., PIECHNA A., 2010, Wyzwania marketingu terytorialnego a kreowanie tożsamości miast w Polsce, (Challenges of territorial marketing and identity creation of Cities in Poland). Publisher Acta Scientiarum Polonorum, Oeconomia 9 (2), pp. 173-190

STANOWICKA-TRACZYK A., 2007, Instrumenty strategii kształtowania wizerunku na przykładzie miast polskich. Kwartalnik „Studia Regionalne i Lokalne”, No. 3 (29), Warszawa, pp. 53-70,.

STRATEGIA ROZWOJU GMINY PISZ NA LATA 2007-2015, (Pisz municipality development strategy).

STUDIUM UWARUNKOWAŃ I KIERUNKÓW ZAGOSPODAROWANIA PRZESTRZENNEGO MIASTA I GMINY PISZ, (Urban planning PISZ TOWNS and municipality).

SUCHACEK J., 2008, Territorial marketing in the Czech Republic: a trial and error process. MPRA Paper No. 15027. Online at http:/ / mpra.ub.uni-muenchen.de/15027/

SZROMNIK A., 2006, Marketing terytorialny - koncepcja ogólna i doświadczenia praktyczne, (Territorial marketing - overall approach and practical experience). W: MARKOWSKI T. (red). Marketing terytorialny. tom CXVI, Komitet Przestrzennego Zagospodarowania Kraju PAN, Warszawa, pp. 33-65.

SZROMNIK A., 2010, Marketing terytorialny: miasto i region na rynku, (Territorial marketing: city nad region on the market), Wolters Kluwer Polska Sp. z o.o., Warszawa.

WAlaciK, M., Grover, R., AdAMUSCIN, A., 2013, Valuation systems in Poland, Slovakia and United Kingdom - comparative study, Real Estate Management and Valuation, Vol. 21, No. 4, pp. 75-86.

ŹRÓBEK S. , ŹRÓBEK R., KURYJ J., 2012, Gospodarka nieruchomościami, (Land management) . wyd. II poszerzone i zaktualizowane, wyd. Gall Katowice, pp. 515

www.pisz.pl 14.04.2013. 
Attachment No. 1

Evaluation questionnaire of marketing activities in the Pisz commune

Statement regarding the marketing orientation of the Pisz commune
Possible variants of answers

$\begin{array}{cccc}\text { yes }(2 & \text { no }(0 & \text { hard to } & \text { results of } \\ \text { points }) & \text { points }) & \begin{array}{c}\text { define } \\ (1 \text { point })\end{array} & \text { questionnaire } \\ & & \end{array}$
(1 point)

1 In your opinion, does the Pisz commune establish longterm contacts and cooperate with foreign entities?

Have you ever received any information on the

2 activities taken by the commune's authorities to gain foreign investors?

3 In your opinion, are the promotional activities of the commune's authorities targeted at potential investors?

4 Do you believe that the image of the Pisz commune is positive when compared with other communes?

In your opinion, is the quality of service for petitioners

5 at the Town and Commune Office of Pisz at the highest level?

Have you ever heard of social consultations conducted

6 by the commune's authorities in order to gain

information on the preferences and expectations of inhabitants?

Do you think that the qualifications of the employees of

7 the town office are suitable for the position held by them?

8 In your opinion, are the decisions made by the commune's authorities compliant with social interest?

Have you ever encountered any difficulties with access

9 to current information on events, issues and decisions made by the authorities?

In your opinion, do the commune's authorities make

10 efforts to foster entrepreneurship and have friendly relations with local companies?

Have you heard of training courses taken by the

11 employees of the town office regarding the issues of petitioners' service?

12 Have you ever come across any false information disclosed by employees or the commune's authorities?

13 Have you ever heard of the commune's participation in fairs or trade exhibitions?

14 Are you satisfied with the atmosphere that prevails in the commune?

15 Does the commune promote its resources sufficiently?

16 Have you ever encountered any sluggishness as regards keeping deadlines by the employees of the town office?

Do you notice any information signs on interesting

17 places, monuments and tourist routes in the area of the

193
commune?

18 Have you ever heard of sports, scientific or cultural events that promote the values of the commune?

19 Do you believe that the tourist and natural values of the commune are demonstrated in promotional activities? 
1. In which three industries do you see prospective growth of the local labor market in the Pisz commune?

Industry

Agriculture

Forestry

Trade

$\cdots$

Fishing

Education

Tourism services

Small services (e.g. cosmetics, redecorating) ....

Other services ( e.g. distribution of electricity, transport)....

other, please specify?

2. Please indicate one industry in which, in your opinion, the Pisz commune should place its marketing efforts.

Agriculture

Trade and services

Forestry

Transport and Telecoms

Tourism

Education

Industry

Other, please specify?.

3. Using the scoring system below, please indicate the activities whose implementation might influence an increase in the competitiveness of the Pisz commune and its general attractiveness.
3-influences greatly
2- influences significantly
1- influences substantially, but not in any particular way
0 - influences slightly or does not influence at all

1. Modernization and development of sanitary and sewage infrastructure - ....

2. Greater communication accessibility, building new communication routes and modernization of the existing ones -.....

3. Improving the natural environment through the implementation of forest and lake treatment programs, pro-environmental education -.....

4. Cooperation with local entrepreneurs with the aim of stimulating the local labor market - ...

5. Pursuing a reliable and regular information policy among inhabitants and other stakeholders -

6. Running revitalization activities in rural and urban areas, aestheticization and use of public lands - ....

7. Expanding the educational offer at local education establishments and setting up a branch of a higher school in the Pisz commune - ...

8. Modernization and extension of leisure and sports facilities with the aim of increasing tourist attractiveness - ...

9. Preparing a comprehensive offer for potential investors - ....

10. Promotion of the commune's values targeted at different groups of recipients - ....

11. Improving qualifications of civil servants and preparing systems of petitioners' service, introducing improvements in procedures - ....

4. Please indicate three activities or measures which, in your opinion, should be taken by the Pisz commune to make its investment offer more attractive.

Granting of concessions and exemptions from local charges and taxes

Sale of land for investments on favorable terms, setting an attractive price for the investor

Comprehensive development of lands for investment from the commune's own resources

Utilizing the commune's own financial means to carry out investments

Transfering the responsiblity for preparing all documentation, applications and contracts onto the commune

Consulting and legal assistance during the preparation and realization of investments

Possibility of paying tax liabilities in instalments or with an extended deadline

Other, please specify?

Source: authors' work based on: HUCZEK 2007 and STANOWICKA - TRACZYK 2007. 